\title{
Guided Inquiry Model To Promote Science Process Skill Students on Acid-Base
}

\author{
Rusly Hidayah and Nurul Lailiy \\ Chemistry Department, Universitas Negeri Surabaya, Surabaya, Indonesia \\ ruslyhidayah@unesa.ac.id
}

\begin{abstract}
This study aims to describe the effectiveness of guided inquiry learning model to train the science process skills of learners on acid-base material grade XI from one public school (Senior High School 1 Bangkalan). The type of this research is descriptive quantitative with "One Group Pretest-Posttest Design". The instruments used for this research are observation sheet of the implementation of the guided inquiry learning model and sheet of the science process skill result. The results of this study shows that (1) the percentage of learning implementation increased, indicating a better quality of learning and (2) the percentage of students' science process skills test results increased as well.
\end{abstract}

Keywords_-Guided Inquiry; Science Process Skills; Acid Base

\section{INTRODUCTION}

Chemistry is obtained and developed based on experiments to find answers to the questions of what, why, and how natural phenomena occur, especially those relating to the composition, structure and nature, transformation, dynamics and energy of substances. Scientists study natural phenomena through processes (observation and experiment) and scientific attitudes (objective and honest when collecting data and analyzing). Scientists use scientific processes and attitudes to obtain or discover chemical products in which some of those can lead to generating facts, theories, laws, and principles or concepts [1].

In terms of learning, such a process is teacher-centered by which students are only accepting and doing what is requested by the teacher. Students are then becoming less active in finding concepts independently. This learning pattern causes the stages found in traditional learning to be opposite to the learning-oriented stages of constructivist theory. In this case the teacher can determine the right learning model, which is not only affects the learning outcomes, but also affects the process skills. Process skills are physical and mental skills related to fundamental abilities that are possessed, mastered and applied in a scientific activity, so that scientists succeed in discovering something new [2]

Learners need to be trained to develop a number of scientific skills that cover observing skills, formulate hypotheses, conduct experiments, conclude and communicate the data. In science learning (chemistry) it is then necessary to use the science process skills approach [3]. Science process skills are not only about formulating hypotheses and determining variables but also involving other skills such as observing, interpreting, and communicating. Science process skills cannot be considered as an insignificant thing in science learning. Students need to be familiarized with the science process skills in order to obtain the correct concepts and to make other high-level thinking skills continues to increase. The more the students use science process skills, the better the results comes related to student conception status (Knowing the Concept) [4].

Inquiry is a learning model that is organized to help students develop an understanding of the processes of natural phenomena and social activities taking place [5]. The use of inquiry models has the aim to support students being able to find and find their own answers to the problems they face like a scientist [6]. Thus, inquiry is considered as a form of learning model that is suitable to train students in solving problems that exist in everyday life. In this study the model used is guided inquiry which is suitable for students who have yet to experience the use of inquiry learning models in terms of gaining more control in students learning.

\section{METHOD}

This type of research is a pre-experimental study. The subjects of this research were students of grade XI-7, science stream, in SMA Negeri 1 Bangkalan. The research design used was One Group Pre-test and Post-test Design:

$$
\mathrm{O}_{1} \quad \mathrm{X}^{\mathrm{O}} \mathrm{O}_{2}
$$

(a) $\mathrm{O}_{1}=$ Pre-test, (b) $\mathrm{X}=$ guided inquiry model, (c) $\mathrm{O}_{2}=$ Posttest

The percentage of the learning implementation was obtained by dividing the number of aspects that were implemented in the learning with the total of aspects multiplied by $100 \%$. The percentage of students' science process skills was obtained by dividing the total score with maximum score multiplied by $100 \%$. The pre-test and post-test scores of science process skills were employed to find the difference.

\section{RESULT}

\section{A. The Implementation of learning}

The implementation of learning is observed by two observers. The lessons were conducted in three meetings. In addition, the lessons obtained a very good percentage. The learning outcomes can be seen in Table 1 . 
TABLE 1. PERCENTAGE OF THE IMPLEMENTATION OF USING GUIDED INQUIRY MODEL

\begin{tabular}{|c|c|c|}
\hline \multirow{2}{*}{ Meeting } & \multicolumn{2}{|c|}{ Result } \\
\cline { 2 - 3 } & Implemented (\%) & Not Implemented (\%) \\
\hline 1 & $94,13 \%$ & 5,87 \\
\hline 2 & $93,72 \%$ & 6,28 \\
\hline 3 & $94,34 \%$ & 5,66 \\
\hline
\end{tabular}

Based on Table 1 it can be seen that the percentage of learning implementation increases which indicates a better quality of learning.

\section{B. Students' Science Process Skills}

The tests of science process skills are conducted twice, before treatment (pre-test) and after treatment (post-test). The difference of those test results can be seen in Figure 1.

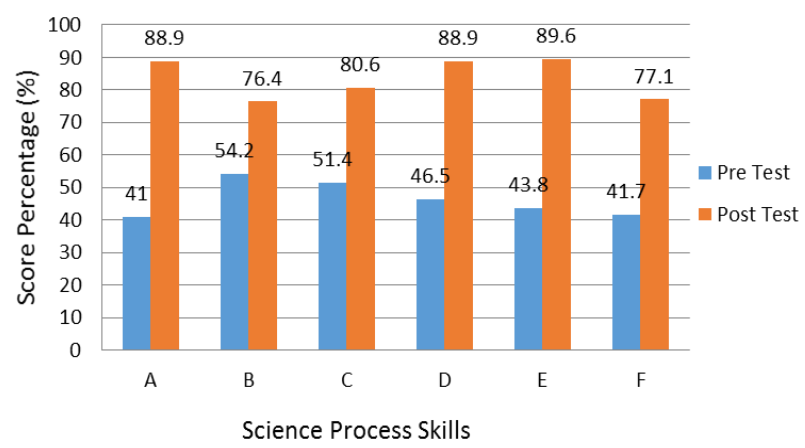

Fig 1. Test Result of Science Process Skills. (A) Observing. (B) Formulating hypotheses. (C) Planing experiment. (D) Interpreting data. (E) Analyzing data. (F) Making conclusion

Based on Figure 1, it can be seen that the percentage of science process skills' score increases from pre-test to post-test. In addition, the pre-test average score is 46.4 and the post-test one is 83.6. The post-test average score is better than the pretest one

\section{DISCUSSION}

Through the results of this study, it can be seen that the percentage of learning implementation increases which indicates better quality of learning. It is because the teacher has mastering on how to implement the guided inquiry learning model. There is no obstacle that occurs, therefore, the teachers can carry out the learning well. The students also look enthusiastic in following the learning process because it provides a fun and enjoyable learning. Students' interests in learning also increases which leads to improvement of students' motivation in learning science [7].

Based on the data above, students can be said to be able to master the observing process skills well, because the post-test results are better than the results of the pre-test, according to Nur [8] observation is to use one or more senses such as vision, listener, smell, taste, and touchers / feelings to gather information about the world. According to Dimyati, and Mudjiono [9] observing process skills are the most basic skills in the process and acquiring knowledge and are the most important things to develop other process skills. Thus, mastering good observation process skills will support students in mastering other process skills. This is in accordance with the research conducted by Siska [10] which states that in terms of learning inquiry can improve the science process skills of students by using the design of one group pretest posttests significantly with an average value of $71.9 \%$. The guided inquiry learning model involves a scientific process, an active exploration that uses critical, logical, and creative thinking skills during learning [11].

The increase of the percentage of students' science process skills' test results occurred because students were already trained to use science process skills. Moreover, the teacher also gives an example of how to formulate the hypothesis and determine the variables first which then followed and imitated by the students. The science process skills were done by the students. So, it only needs to be observed and clarified if there is an error. In brief, the guided inquiry model successfully enriches the students' knowledge and improves the science process skills [12].

\section{CONCLUSION}

Based on the results of the study, it can be concluded that guided inquiry model is effective to improve students' science process skills seen from the improvement of students' test results.

\section{REFERENCES}

[1] Kemendikbud, "Lampiran Peraturan Menteri Pendidikan dan Kebudayaan RI Nomor 54 Tahun 2014. Standart Lulusan Dasar dan Menengah", Jakarta: Kementerian dan Kebudayaan, 2014.

[2] M. I. Usman, "Model Mengajar Dalam Pembelajaran: Alam Sekitar, Sekolah Kerja, Individual, dan Klasikal”, Lentera Pendidikan 2, 2012, pp. 251-266.

[3] C. Semiawan, S. Belen, and A. F. Tangyoung, "Pendekatan Keterampilan Proses Bagaimana Mengaktifkan Siswa dalam Belajar", Jakarta: PT. Gramedia, 1992.

[4] N Lutfi and Suyono, "Dependensi Jenjang Keterampilan Proses Sains Dan Jenjang Konsepsi Siswa Pada Materi Stoikiometri”, Unesa Journal Of Chemical Education 3, 2014, pp. 153-160

[5] R. I. Arends, "Learning to Teach Ninth Edition", New York: The McGraw-Hill Companes-Hill Companes, Inc., 2012.

[6] IB. Siwa, I W. Muderawan, and N. Tika, "Pengaruh Pembelajaran Berbasis Proyek Dalam Pembelajaran Kimia terhadap Keterampilan Proses Sains Dari Gaya Kognitif Siswa”, E-journal Program Pascasarjana Universitas Pendidikan Ganesha 3, 2013, pp. 1-13

[7] M. Nur, "Teori-Teori Perkembangan", Surabaya: Unesa University Press, 1998

[8] M. Nur, "Modul Keterampilan-keterampilan Proses Sains", Surabaya: Universitas Negeri Surabaya Pusat Sains dan Matematika Sekolah, 2011.

[9] Dimyati and Mudjiono, "Belajar dan Pembelajaran", Jakarta: Rineka Cipta, 2013.

[10] M. B. Siska, "Peningkatan Keterampilan Proses Siswa SMA Melalui Praktikum Berbasis Inkuiri pada Materi Laju Reaksi”, Penelitian Riset dan Praktik Pendidikan Kimia, Vol.1, No.1, 2013.

[11] D. Llewellyn, "Teaching High School Science Through Inquiry", USA: Corwin Press, 2005.

[12] A. Lutfi, and R. Hidayah, "Training Science Process Skills Using Virtual Laboratory On Learning Acid, Base, And Salt" Journal of Chemistry Education Research 2, 2018, pp. 49-54 